\title{
The social inequity across the smoking social costs
}

\author{
Efraín Sánchez González $\mathrm{MD}^{1}$ and FéFernández Hernández $\mathrm{MD}^{1 *}$ \\ ${ }^{1}$ Faculty of Medical Science, University of Medical Science of Havana, Cuba
}

${ }^{*}$ Corresponding Author: FéFernández Hernández, Faculty of Medical Science, University of Medical Science of Havana, Calle 146 No. 2504 Playa municipality. Havana. Cuba; Tel: +5378791313; E-mail: fefh@infomed.sld.cu

Received: November 14, 2019; Accepted: November 21, 2019; Published: November 25, 2019;

\begin{abstract}
Introduction: Tobacco consumption is a demonstrated cause of growing in morbidity and mortality between smokers. Because of that it influence hardly since the social and the economic context because of smoking social costs. Consequently these costs are determining a particular inequity according to the smoking impact.
\end{abstract}

Objective: To describe the main economics characteristics that identify to smoking like inequity cause.

Materials and methods was made a descriptive research about the main characteristics that identify to smoking as social inequity cause. Were utilized the inductive deductive like theoretical method and like empiric was utilized the bibliographic research.

Results: The inequity attributable to smoking is given by the social cost attributable to it. The direct cots by morbidity determine a socio epidemiologic inequity while the indirect cost by labor productivity loses condition a socio labor inequity. Both costs are determining a contextualized form of socioeconomic inequity.

Conclusion: The economic burden attributable to smoking is a main measurer for the socioeconomic inequity attributable to smoking. The indirect costs attributable to smoking are given mainly by labor productivity lose attributable to smoking. In these cases the labor time lose in each context is a main measurer for the social inequity attributable to smoking by this way.

Keywords: Cost, Inequity, Smoking

\section{Introduction}

Smoking is an accumulative, modifiable and socioeconomic risk factor. These classifications are a strong base to understand by the society and the fiscal authority particularly about smoking to control it. That's why the analysis about smoking cost by cost type will contribute to apply more efficient fiscal policies for the smoking control [1]. Like socioeconomic risk factor smoking have two main variables given by the smoker number and the tobacco consumption. Then, the relation saved by these variables explicates the smoking behavior too [2]. The single variation in both carries to smoking variation in the same way. Consequently the smoking social costs are in direct relation to these variables and the smoking social inequity too. As consequence of the tobacco growing it produces high social cost irreversible at short time. These costs overcharge to no smokers and thus born the smoking social inequity. The smoking social inequity form will depend from the smoking impact over the population researched but generally is possible to determine an economic cost because of the smoking social inequity too [3]. The most evident case is the passive smokers who are exposed to tobacco smoke and because of that suffers the smoking consequences agree to the exposition rate. Then, each form to measure the smoking social inequity must include these main variables and must be agree to the smoking particularities too [4].

\section{Social inequity across smoking social cost}

Tobacco consumptions carry to health disequilibrium. This is because the smoking social impact over the health population and the real health services too. This disequilibrium determines the smoking social inequity by smoking direct cost [5]. Smoking like socioeconomic risk factor is close related with poorness and the human develop. WHO had pointed the close relation between tobacco consumption and the health services demand and the economic development because of labor productivity lose too. These are the bases for the smoking social inequity by labor productivity loses attributable to smoking $[5,6]$. These arguments show how important is understand the smoking social inequity like untouchable smoking impact. That's why the objective of this research is to describe the main characteristic that identify to smoking as social inequity cause.

\section{Materials and methods}

Was made a descriptive research about the main characteristics that identify to smoking as social inequity cause. Were utilized the inductive deductive like theorical method and like empiric was utilized the bibliographic research. 


\section{Results}

The social inequity because of smoking is given by the disparities in the society because of the smoking social costs. The most important social cost attributable to smoking are the direct smoking cost related with morbidity and the health services and the indirect smoking cost related with the labor productivity lose related with morbidity and mortality because of smoking. Each of them has particular forms of social inequity attributable to smoking [6].

\section{Inequity attributable to smoking in the consumption of health services}

A significant part of the health budget is utilized attending morbidities causes attributable to smoking. Then, the no existence of smoking should mean an important social save that could able for other social objectives [7]. This disparity is given by the smoking impact over active and passive smokers. This social impact it shows by the effective demand of health services because of smoking, the smokers' number and the morbidity attributable to smoking. That is why the economic burden is a main measurer rate for the social inequity attributable to smoking for the Public Health [7].

\section{Socio-epidemiologic and socioeconomic social ineq- uity across the direct social attributable to smoking}

To understand the social inequity attributable to smoking since the direct social costs is necessary to difference between epidemiologic burden and economic burden attributable to smoking [8,9]. The epidemiologic burden is given by the morbidity attributable to smoking like risk factor and represents the morbidity probability's attributable to smoking. By other side the economic burden is given by the effective demand of health services attributable to smoking. It is equivalent to the health spend probability's attributable to smoking $[8,9]$. The morbidity attributable to smoking creates disparities in the incidence of morbidity causes related with smoking. This disparities are given by the smoking impact over the health and it show in the differences between smokers morbidity and no smokers morbidity. This type of disparity explicates the socio-epidemiologic inequity attributable to smoking, where the epidemiologic burden is the main explicative variable $[8,9]$. The morbidity attributable to smoking carries to disparities accessing to the health services too. These disparities should be external or internal. The external are given by the exclusion of consumer from the health services market while the internal are given by the redistribution in the health services accessing attributable to smoking. These are the main socioeconomic inequities attributable to smoking across the direct social costs attributable to smoking.

\section{Socio-labor and socioeconomic inequity because of the labor productivity lose attributable to smoking}

The labor productivity lose attributable to smoking can be absolute or relative. The absolute is related with earlier death because of smoking while the relative is associated to the morbidity attributable to smoking [10]. The earlier death of smoker reduces the life expectative and this is an important social inequity given by the difference in life expectation between smokers and no smokers because of smoking. Also, is smoker death occur before retire age is present a socio-labor inequity because of the potential work time lose because of smoking and a socioeconomic inequity because of all economic benefits no obtained because of smoking given by the smoker earlier death [11]. The relative labor lose attributable to smoking can be by touchable absenteeism or untouchable absenteeism. The touchable absenteeism occur when the smoker worker isn't physically present at workplace because of the morbidity attributable to smoking while the untouchable absenteeism occur when the smoker worker use part from the labor time to smoke although keep physically at workplace [10-12]. Each labor productivity lose will depend from the specific characteristic of the smoking impact. In general way can be identified two main social inequity form because of labor productivity lose attributable to smoking: a socio-labor inequity and a socioeconomic inequity. The socio-labor inequity is determined by the potential labor time lose because of smoking and the socioeconomic inequity is determined by all economic costs related to each social inequity form attributable to smoking by labor productivity lose. In general way, understand the social inequity attributable to smoking by all causes may adopt better social policies agree with the particular smoking impact. That's why the smoking control is interesting for all societies but specially for the fiscal authorities $[13,14]$.

\section{Conclusion}

The smoking social costs are the best measure rate for the smoking social inequity. The direct social costs by morbidity determine the socio-epidemiologic and the socioeconomic inequity attributable to smoking by this way. In this case the epidemiologic burden and the economic burden are the main rate to explain the social inequity attributable to smoking by the smoking direct costs. By other side, smoking social costs by labor productivity lose attributable to smoking determine the socio-labor inequity and the socioeconomic inequity because of labor productivity lose attributable to smoking. In this case the potential labor time lose determines this social inequity.

\section{References}

1. Toledo Curbelo GJ (2008) Fundamentos de Salud Pública. Segunda edición. Pág La Habana: Ciencias Médicas Pg No: 184-186.

2. Fernández Hernández F, Sánchez González E (2018) Algorithm to calculate the smoking economical burden in active and passive smokers. MOJ Toxicol 4: 373375 .

3. Fernández Hernández F, Sánchez González E (2019) La carga económica del tabaquismo. España: Editorial Académica Española.

4. Varona Pérez P, García Roche G, Willams Fogarty A, Britton J (2015) Mortalidad por cáncer de pulmón y cardiopatía isquémica atribuible al tabaquismo pasivo en Cuba - 2011. Rev Cubana HigEpidemiol 53. Disponible en: http://www. revepidemiologia.sld.cu/index.php/hie/article/view/55.

5. Fernández Hernández F, Sánchez González E (2019) Economic Inequity Attributable to Smoking Ratio's for the Public Health. Health Econ Outcome Re Open Access 4: 161

6. Fernández Hernández F, Sánchez González E (2019) The socioeconomic inequity attributable to smoking. Journal of Medical Practice and Review 3: 559-562. Disponible en http://jmpr.info/index.php/jmpr/index,

7. Fernández Hernández F, Sánchez González E (2017) Impacto del tabaquismo en el presupuesto sanitario de Cuba 1997-2014. Revista del Hospital Psiquiátrico de La Habana 14. Disponible en: http://revhph.sld.cu/index.php/hph/article/view/31.

8. Sánchez González E, Fernández Hernández F (2019) A view for the morbidity attributable to smoking since the microeconomic. Trends in Research 2: 1-2. 
FéFernández H (2019) The social inequity across the smoking social costs

9. Fernández Hernández F, Sánchez González E (2017) Carga epidemiológica vs carga económica del tabaquismo por morbilidad. Rev Ciencias Médicas 21: 60-66. Disponible en: http://scieloprueba.sld.cu/scielo.php?script=sci arttext\&pid=S1561-31942017000200009\&lng=es,

10. Sánchez González E, Fernández Hernández F (2016) La pérdida de productividad laboral atribuible al tabaquismo. Revista Cubana de Salud y Trabajo 17: 57-60.

11. Sánchez González E, Fernández Hernández F (2018) Costo social por pérdida absoluta de productividad laboral. Revista Cubana de Salud y Trabajo 19: 33-39.

12. Fernández Hernández F, Sánchez González E (2017) Pérdida de productividad por el consumo de cigarrillos en la jornada laboral. Revista Cubana de Salud y Trabajo 18: 9-12.
13. Sánchez González E, Fernández Hernández F (2018) La relación entre la política tributaria y el control del tabaquismo en Cuba. CCM 22: 238-249. Disponible en: http://scieloprueba.sld.cu/scielo.php?script=sci_arttext\&pid=S1560$43812018000200005 \& \operatorname{lng}=$ es.

14. Sánchez González E, Fernández Hernández F (2017) El rol de las autoridades fiscales en el control del tabaquismo. Rev Ciencias Médicas 21: 62-67. Disponible en: http://scielo.sld.cu/scielo.php?script=sci_arttext\&pid=S156131942017000300010\&lng=es.

\section{Citation:}

González ES, FéFernández H (2019) The social inequity across the smoking social costs. Ageing Sci Ment Health Stud Volume 3(5): 1-3. 